\title{
Analisis Ketimpangan dan Faktor Yang Mempengaruhi Tingkat Ketimpangan Antar Kabupaten/Kota Di Provinsi Jawa Barat
}

\author{
Rizki Silviana, Amandus Jong Tallo \\ Fakultas Teknik dan Ilmu Komputer, Universitas Bakrie \\ rizki7silviana@gmail.com mandustallo@gmail.com
}

Received: 08 Juli 2020; Revised: 21 Agustus 2020; Accepted: 28 Agustus 2020

DOI: http://dx.doi.org/10.37905/aksara.6.2.97-102.2020

\begin{abstract}
Abstrak
Provinsi Jawa Barat didukung oleh 17 sektor lapangan usaha dengan sumbangan tertinggi dari 3 sektor yaitu, sektor Industri Pengolahan sebesar 43,37 \%, sektor Perdagangan Besar dan Eceran; Reparasi Mobil dan Sepeda Motor sebesar 15,60 \% dan sektor Konstruksi sebesar 8,21\%. Ketimbangan antar kabupaten/kota di Provinsi Jawa Barat berdasarkan Indeks Williamson masuk kedalam kategori tinggi sekitar 1,43 yang terjadi di wilayah Tasikmalaya. Metode analisis tipologi klassen terbagi menjadi 4 klasifikasi pendekatan wilayah yaitu, Kuadran I (Daerah maju dan tumbuh cepat), Kuadran II (Daerah maju tapi tertekan), Kuadran III (Daerah berkembang cepat), dan Kuadran IV (Daerah tertinggal). Faktor utama penyebabkan terjadinya ketimpangan antar wilayah yaitu, perbedaan sumberdaya alam, perbedaan kondisi demografis, kurang lancarnya mobilitas barang dan jasa, konsentrasi kegiatan ekonomi wilayah, dan alokasi dana pembangunan antar wilayah yang berbeda-beda.

Kata Kunci: Jawa Barat, PDRB, Ketimpangan Ekonomi, Faktor Ketimpangan.
\end{abstract}

\begin{abstract}
West Java Province is supported by 17 business sectors with the highest contribution from 3 sectors, namely the Manufacturing Industry sector at $43.37 \%$, the Wholesale and Retail Trade sector; Car and Motorcycle Repair was $15.60 \%$ and the Construction sector was $8.21 \%$. The balance between regencies / cities in West Java Province based on the Williamson Index falls into the high category of around 1.43 which occurred in the Tasikmalaya region. Klassen's typology analysis method is divided into 4 regional approach classifications namely, Quadrant I. (Regions growing and growing fast), Quadrant II. (Regions developed but depressed), Quadrant III. (Regions developing fast), and Quadrant IV. (Regions lagging). The main factors causing inequality between regions are, differences in natural resources, differences in demographic conditions, poor mobility of goods and services, concentration of regional economic activity, and allocation of development funds between regions.
\end{abstract}

Keywords: West Java, GRDP, Economic Inequality, Inequality Factors.

\section{PENDAHULUAN}

Indonesian merupakan negara kepulauan yang memiliki beberapa provinsi dengan berbagai macam karakteristik dan sumberdaya alam yang berbeda-beda. Setiap provinsi memiliki pertumbuhan ekonomi yang beragam yang menunjukkan pertumbuhan produksi barang dan jasa di suatu wilayah perekonomian dalam selang waktu tertentu. Data Badan Pusat Statistik Indonesia pertumbuhan ekonomi tertinggi di Pulau Jawa berasal dari Provinsi Jawa Tengah dengan PDRB yang diukur atas dasar harga konstan tahun 2019 tumbuh sekitar 5,80\%. Sedangkan Provinsi Jawa Timur tumbuh sekitar 5,52 \%, disusul dengan Provinsi Banten dengan pertumbuhan ekonomi sekitar 5,35 \%, dan pertumbuhan ekomoni Jawa Barat sekitar 5,07 \%. Dengan kata lain jika dibandingkan dengan 
pertumbuhan ekomoni dibeberapa wilayah Provinsi di Pulau Jawa, maka pertumbuhan ekomoni Jawa Barat berada di posisi terendah.

Pertumbuhan ekonomi di Provinsi Jawa Barat pada tahun 2019 rata-rata sebesar $5,07 \%$ jika dibandingkan dengan pertumbuhan ekonomi nasional yang tercatat sebesar $5,02 \%$, maka pertumbuhan ekonomi Jawa Barat lebih tinggi. Namun jika dibandingkan dengan tahun 2018 yang mencapai 5,66 \% maka saat ini tumbuh melambat. Perlambatan ekonomi pada tahun 2019 tidak lepas dari kondisi ketidakpastian ekonomi global, perang dagang AS-China yang menahan kinerja ekspor - impor, serta pengaruh politik di dalam negeri. Namun demikian, permintaan domestik masih kuat seiring dengan rata-rata kenaikan UMK Jawa Barat sebesar 8,11\%. (Wahyu, Kiki Sarah, 2020).

Selain pertumbuhan ekonomi Provinsi, pertumbuhan ekonomi wilayah Kabupaten/kota juga merupakan hal penting yang harus diperhatikan agar pertumbuhan, pemerataan dan keberlanjutan pembangunan berimbang pada setiap wilayah-wilayah Kabupaten/kota. Saat ini ada 27 Kabupaten/kota di Provinsi Jawa Barat dengan karakteristik sumberdaya alam, ekonomi, dan demografi yang berbeda-beda. Sehingga pertumbuhan ekonomi yang tinggi tidak terjadi di seluruh wilayah. Berdasarkan PDRB Jawa Barat, ada beberapa wilayah kabupaten/kota yang memiliki pertumbuhan ekomoni wilayah yang tinggi, seperti wilayah Bekasi sekitar 16,81 \%, Kota Bandung 12,47 \%, dan Karawang 10,95\%. Sedangkan kabupaten/kota lainnya hanya dapat menghasilkan sedikit pertumbuhan ekonomi. Jika pemerintah pusat maupun pemerintah daerah terus membiarkan hal ini, maka akan terjadi kesenjangan atau ketimpangan dalam proses pembangunan antar daerah. Menurut (Saputra, 2004) Regional Income Disparities (Ketimpangan antar daerah) dapat menimbulkan kecemburuan sosial, disparitas ekonomi yang semakin tajam dan perpecahan antar wilayah. Sehingga penelitian ini bertujuan menganalisis ketimpangan dan faktor yang mempengaruhi tingkat ketimpangan antar (kabupaten/kota) di Provinsi Jawa Barat saat ini.

\section{METODE}

1. Indeks Williamson

Metode Indeks Williamson digunakan untuk mengidentifikasi sektor unggulan berdasarkan potensi ekonomi daerah dan mengetahui tingakt ketimpangan yang terjadi. (Sutarno, 2003).

$$
\begin{aligned}
& \text { Rumus Indeks Williamsor } \\
& \text { Keterangan: } \\
& I W Z \frac{\sqrt{\sum_{i \mathrm{ZN}}^{n} \mathrm{E} Y i-Y \mathrm{P}^{0} \mathrm{E} \frac{f i}{n} \mathrm{~F}}}{Y} \\
& \text { IW : Indeks Williamson } \\
& \text { Fi : Jumlah Penduduk di Kabupaten/kota di Provinsi Jawa Barat } \\
& \text { n : Jumlah Penduduk di Provinsi Jawa Barat } \\
& \text { Yi : PDRB Perkapita di Kabupaten/kota di Provinsi Jawa Barat } \\
& \text { Y : PDRB Perkapita di Provinsi Jawa Barat }
\end{aligned}
$$

\section{Analisis Klassen Typologi}

Menurut (Tallo et al., 2018) Analisis Klassen Typologi bertujuan untuk mengetahui posisi relatif ekonomi di suatu wilayah yang lebih luas, indikator 
Bulan : September 2020

Tahun : 2020

http : //ejurnal.pps.ung.ac.id/index.php/Aksara

pertumbuhan ekonomi dan pendapatan PDRB per kapita, melalui empat klasifikasi pendekatan wilayah.

Tabel 1. Klasifikasi Klassen Typologi

\begin{tabular}{|c|c|c|}
\hline & $Y_{i j}>\bar{Y}_{j}$ & $Y_{i j}<Y_{j}$ \\
\hline \multirow{2}{*}{$R_{i j}>\bar{R}_{j}$} & Kuadran I & Kuadran III \\
& Daerah maju dan tumbuh cepat & Daerah berkembang cepat \\
\hline \multirow{2}{*}{$R_{i j}<\bar{R}_{j}$} & Kuadran II & Kuadran IV \\
& Daerah maju tapi tertekan & Daerah tertinggal \\
\hline
\end{tabular}

Keterangan:

Rij : Nilai rerata laju pertumbuhan sektor i di wilayah perencanaan j Ri

: Nilai rerata laju pertumbuhan sektor i di wilayah yang lebih luas Yij

: Nilai rerata kontribusi i terhadap ekonomi wilayah perencanaan j Yi

: Nilai rerata kontribusi sektor i terhadap wilayah yang lebih luas

\section{HASIL DAN PEMBAHASAN}

\section{PDRB Provinsi Jawa Barat Berdasarkan Sektor Lapangan Usaha}

Berdasarkan BPS Provinsi Jawa Barat saat ini, pemasukan PDRB didukung oleh 17 sektor lapangan usaha atas dasar harga konstan pada periode tahun 2015-2019 sebagai berikut:

Tabel 2. PDRB Provinsi Jawa Barat menurut Lapangan Usaha tahun 2015-2019 (Juta Rupiah)

\begin{tabular}{|c|c|c|c|c|c|c|c|c|c|}
\hline \multirow{2}{*}{ No } & \multirow{2}{*}{ Kategori } & \multirow{2}{*}{ ektor } & 2015 & 2016 & 2017 & 2018 & 2019 & \multirow{2}{*}{ Tata-rate } & \multirow{2}{*}{ Persentase } \\
\hline & & & (l) & (2) & (3) & (4) & (5) & & \\
\hline 1 & A & Pertanian, Kehtranan, dan Perikanan & $92,653,584.24$ & 92,802,798.97] & $98,096,580.31$ & $99,669,370.03$ & $101,777,202.76$ & $96,999,907.26$ & $7.58 \%$ \\
\hline 2 & B & Pertambangan dan Pengyalizn & $27,291,421.36$ & $27,403,820.15$ & $27,138,684.60$ & $26,589,926.88$ & $25,496,225.87$ & $26,784,015.77$ & $2.09 \%$ \\
\hline 3 & c & Industri Pengolahan & $502,433,623.07$ & $524,466,677.04$ & $549,471,383.78$ & $578,858,482.37$ & $616,441,684.99$ & $554,334,370.25$ & $43.34 \%$ \\
\hline 4 & D & Pengadzan Listrik dan Gas & $6,373,286.03$ & $5,939,653.36$ & $6,139,545.25$ & $5,438,106.38$ & $5,438,947.93$ & $5,865,907.79$ & $0.46 \%$ \\
\hline 5 & E & $\begin{array}{l}\text { Pengadazn Air, } \\
\text { Limbah dan } D_{2 a}\end{array}$ & $896,263.79$ & $948,977.84$ & $1,009,018.45$ & $1,080,964.63$ & $1,134,533.19$ & $1,013,951.58$ & $0.08 \%$ \\
\hline 6 & $\mathrm{~F}$ & Konstruksi & $92,603,491.63$ & $98,555,254.72$ & $103,507,0699.45$ & $111,001,029.17$ & $119,305,155.02$ & $104,994,400.00$ & $8.21 \%$ \\
\hline 7 & G & $\begin{array}{l}\text { Perdagzangan Besara dan Eceran; } \\
\text { Reparasi Mobil dan Sepeda Moto }\end{array}$ & $183,634,922.83$ & $190,440,113.16$ & $198,865,387.31$ & $207,909,713.33$ & $216,613,826.81$ & $199,492,792.69$ & $15.60 \%$ \\
\hline 8 & $\mathrm{H}$ & Transportasi dan Pergudangan & $51,579,514.10$ & $56,320,031.81$ & $61,297,384.59$ & $64,258,641.57$ & $67,701,976.39$ & $231,509.69$ & $4.71 \%$ \\
\hline 9 & I & $\begin{array}{l}\text { Penyediazn Akomodasi dan Makan } \\
\text { Minum }\end{array}$ & $5,028.81$ & 22 & $32,559,353.38$ & $35,285,421.71$ & $38,160,143.18$ & $32,665,298.66$ & $2.55 \%$ \\
\hline 10 & $\mathrm{~J}$ & Informasi dan Komvnikasi & $36,005,412.36$ & $41,878,751.58$ & $47,856,799.53$ & $53,527,156.09$ & $58,420,751.33$ & $47,537,774.18$ & $3.72 \%$ \\
\hline 11 & $\mathrm{~K}$ & Jasa Kevangan dann Astransi & $27,497,251.44$ & $29,521,633.81$ & $33,030,521.52$ & $34,179,944.74$ & $35,727,388.51$ & $31,991,348.00$ & $2.50 \%$ \\
\hline 12 & $\mathrm{~L}$ & Real Estate & $13,121,319,37$ & $13,837,689.48$ & $14,738,072.12$ & $16,109,923.50$ & $17,663,387.11$ & $15,094,078.32$ & $1.18 \%$ \\
\hline 13 & $\mathrm{M}, \mathrm{N}$ & Jasa Pervashaza & $4,561,081.01$ & $4,932,613.38$ & $5,334,980.44$ & $5,784,330.04$ & $6,284,130,74$ & $5,379,427.12$ & $0.42 \%$ \\
\hline 14 & 0 & $\begin{array}{l}\text { Adminisitrasis Pemes } \\
\text { Pertahanan dan Jan }\end{array}$ & $23,676,877.00$ & $24,987,382.17$ & $25,739,066.98$ & $26,933,346.19$ & $27,360,564.73$ & $25,739,447.41$ & $2.01 \%$ \\
\hline 15 & $P$ & Jasa Pendidikan & $29,424,905.69$ & $32,418,865.50$ & $34,885,810.90$ & $37,909,721.09$ & $40,075,480.26$ & $34,942,956.69$ & $2.73 \%$ \\
\hline 16 & Q & Jasa Keshhatan dan Kegiatan Sosial & $7,780,534.33$ & $8,880,758.33$ & $9,723,042.98$ & $10,537,792.90$ & $11,369,959.23$ & $9,658,417.55$ & $0.76 \%$ \\
\hline 17 & S,T,U & Jass lainnya & $22,137,539.99$ & $24,120,774.04$ & $26,226,539.58$ & $28,790,561.55$ & $30,717,757.85$ & $26,398,634.60$ & $2.06 \%$ \\
\hline & & JUMLAH & $1,149,216,057,05$ & $1,207,232,341.56$ & $1,275,619,241.17$ & $1,343,864,432.17$ & $1,419,689,115,90$ & $1,279,124,237.57$ & $100.00 \%$ \\
\hline
\end{tabular}

Sumber : Pribadi/Hasil penelitian

Berdasarkan dari data pertumbuhan ekonomi di Provinsi Jawa Barat dari ke 17 sektor lapangan usaha, maka setiap sektor lapangan usaha memberikan sumbangan yang 
berbeda-beda terhadap PDRB Provinsi Jawa Barat sepanjang tahun 2015 - 2019. Jika dilihat dari sisi produksi pertumbuhan tertinggi disumbang dari 3 sektor lapangan usaha yaitu, sektor Industri Pengolahan sebesar 43,34 \%, lalu disusul oleh sektor Perdagangan Besar dan Eceran; Reparasi Mobil dan Sepeda Motor sebesar 15,60 \% dan sektor Konstruksi sebesar 8,21\%. Selain itu terdapat 3 sektor lapang usaha yang memberikan sumbangan terkecil terhadap PDRB Provinsi Jawa Barat yaitu, sektor Pengadaan Listrik dan Gas sebesar 0,46 \%, disusul sektor Jasa Perusahaan sebesar 0,42 \%, dan sektor Pengadaan Air, Pengelolaan Sampah, Limbah dan Daur Ulang sebesar 0,08 \%. Hal ini bisa disebabkan karena kondisi geografis, sumberdaya alam, dan jumlah penduduk di yang sangat beragam.

2. Tingkat Ketimpangan Antar Wilayah di Provinsi Jawa Barat Tahun 2015-2019

Tingkat ketimpangan yang terjadi antar wilayah pada tahun 2015-2019 dinilai dari besar kecilnya ketimpangan PDRB Provinsi Jawa Barat, sehingga memberikan gambaran tentang perkembangan pembangunan setiap wilayah. Berdasarkan hasil analisis Indeks Williamson, jika tingkat ketimpangan antar wilayah semakin kecil menandakan pendapatan suatu wilayah semakin merata, sehingga nilai IW harus mendekati nol (0). Namun jika nilai IW semakin besar atau semakin mendekati satu $(>1)$ maka pendapatan wilayah tidak merata, sehingga ketimpangan antar wilayah tersebut semakin tinggi.

Menurut (Puspandika, 2007) jika nilai IW diatas 0,50 menandakan tingkat ketimpangan yang tinggi antar wilayah. Rata-rata angka Indeks Williamson di Kabupaten/kota pada tahun 2019 menunjukkan angka 0,89 yang artinya diatas 0,50. Hal ini menjelaskan bahwa terjadi ketimpangan antar wilayah kabupaten/kota yang cukup tinggi pada tahun 2019, meskipun perekonomian Provinsi Jawa Barat mengalami peningkatan setiap tahunnya. Sehingga pemerintah Provinsi Jawa Barat perlu melakukan upaya-upaya yang lebih mendalam untuk mengurangi tingkat ketimpangan yang terjadi antar kabupaten/kota dengan meningkatkan pembangunan infrastruktur dan penyebaran pusat-pusat pertumbuhan ekonomi. 
Bulan : September 2020

Tahun : 2020

http : //ejurnal.pps.ung.ac.id/index.php/Aksara

Tabel 3. Perhitungan Indeks Williamson Antar

\begin{tabular}{|c|c|c|}
\hline No & Wilayah Jawa Barat & $\mathbf{I w}$ \\
\hline 1 & Bogor & 0.76 \\
\hline 2 & Sukabumi & 1.06 \\
\hline 3 & Cianjur & 1.42 \\
\hline 4 & Bandung & 0.92 \\
\hline 5 & Garut & 1.34 \\
\hline 6 & Tasikmalaya & 1.43 \\
\hline 7 & Ciamis & 1.09 \\
\hline 8 & Kuningan & 1.28 \\
\hline 9 & Cirebon & 1.30 \\
\hline 10 & Majalengka & 1.13 \\
\hline 11 & Sumedang & 0.96 \\
\hline 12 & Indramayu & 0.58 \\
\hline 13 & Subang & 1.12 \\
\hline 14 & Purwakarta & 0.42 \\
\hline 15 & Karawang & 0.29 \\
\hline 16 & Belcasi & 0.30 \\
\hline 17 & Bandung Barat & 1.08 \\
\hline 18 & Pangandaran & 1.03 \\
\hline 19 & Kota Bogor & 0.69 \\
\hline 20 & Kota Sukabumi & 0.76 \\
\hline 21 & Kota Bandung & 0.25 \\
\hline 22 & Kota Cirebon & 0.38 \\
\hline 23 & Kota Bekasi & 0.87 \\
\hline 24 & Kota Depok & 0.98 \\
\hline 25 & Kota Cimahi & 0.54 \\
\hline 26 & Kota Tasikmalaya & 0.84 \\
\hline 27 & Kota Banjar & 1.14 \\
\hline \multicolumn{2}{|c|}{ Jumlah } & 23.96 \\
\hline \multicolumn{2}{|c|}{ Rata-rata } & 0.89 \\
\hline
\end{tabular}

Kabupaten/Kota Tahun 2019

Sumber : Pribadi/Hasil penelitian 


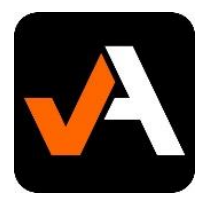

Volume : 06

Nomor : 03

Bulan : September 2020

Tahun : 2020

http : //ejurnal.pps.ung.ac.id/index.php/Aksara

INDEKS WILLIAMSON PROVINSI JAWA BARAT MENURUT KABUPATEN/KOTA 2019 (PER MASING-MASING WILAYAH)

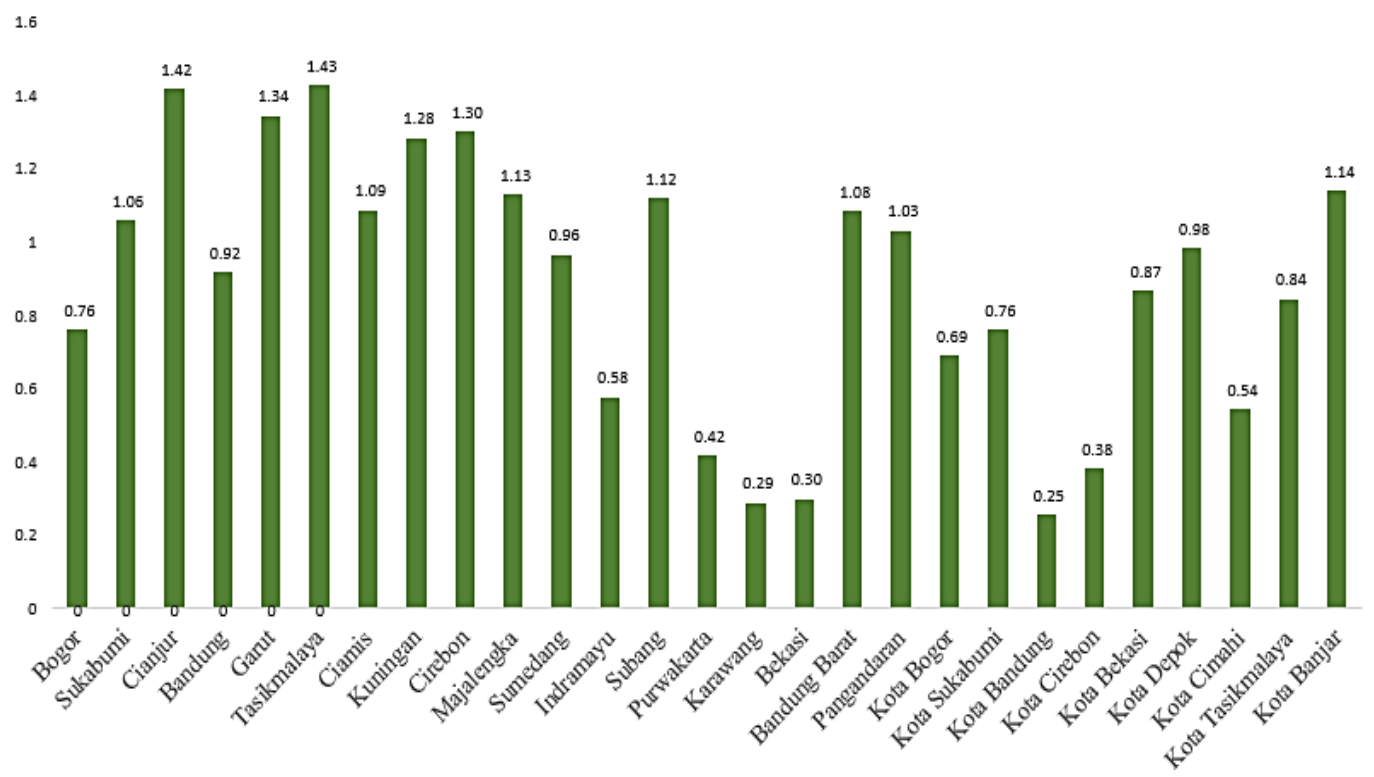

Grafik 1 : Indeks Williamson Antar Kabupaten/Kota Tahun 2019

Berdasarkan data yang ada, menunjukan tingkat ketimbangan kabupaten/kota di Provinsi Jawa Barat masuk kedalam kategori tinggi, beberapa wilayah dengan ketimpangan tertinggi terjadi pada wilayah Tasikmalaya dengan Indeks Williamson (tingkat ketimpangan) sebesar 1,43, disusul dengan wilayah Cianjur sebesar 1,42, wilayah Garut sebesar 1,34, wilayah Cirebon sebesar 1.30 dan disusul dengan wilayah Kuningan sebesar 1.28. Sementara itu wilayah dengan nilai Indeks Williamson (tingkat ketimpangan) terendah yaitu berada diwilayah Kota Bandung dengan nilai 0,25, kemudian wilayah Karawang 0,29, dan Bekasi 0,30. Hal ini menandakan bahwa tingkat pendapatan ekonomi pada wilayah tersebut termasuk kategori merata.

3. Klasifikasi Kabupaten/kota di Provinsi Jawa Barat Tahun 2015-2019

Berdasarkan Klassen Typologi kemajuan pembangunan ekonomi setiap kabupaten/kota menjadi empat klasifikasi yaitu, pengklasifikasian kabupaten/kota berdasarkan Klassen Typologi di Provinsi Jawa Barat, dapat dilihat pada Tabel 3 sebagai berikut. 
Tabel 5. Klasifikasi Kabupaten/kota Provinsi Jawa Barat tahun 2015-2019

\begin{tabular}{|c|c|c|}
\hline $\begin{array}{l}\text { PDRB Per } \\
\text { Kapita Laju } \\
\text { petumbuhan }\end{array}$ & $\mathbf{Y} \mathbf{i}>\mathbf{Y}$ & $\mathbf{Y} \mathbf{i}<\mathbf{Y}$ \\
\hline \multirow[b]{2}{*}{$\mathbf{R} \mathbf{i}>\mathbf{R}$} & $\begin{array}{c}\text { Daerah maju dan tumbuh } \\
\text { cepat }\end{array}$ & Daerah berkembang cepat \\
\hline & $\begin{array}{c}\text { Karawang, Kota Bandung, } \\
\text { Kota Cirebon }\end{array}$ & $\begin{array}{l}\text { Bogor, Cianjur, Bandung, Kuningan, } \\
\text { Majalengka, Sumedang, Kota Bogor, } \\
\text { Kota Bekasi, Kota Depok, } \\
\text { Kota Tasikmalaya }\end{array}$ \\
\hline & Daerah maju tapi tertekan & Daerah tertinggal \\
\hline $\mathbf{R} \mathbf{i}<\mathbf{R}$ & $\begin{array}{l}\text { Kabupaten Bekasi, } \\
\text { Bandung Barat, } \\
\text { Kota Banjar }\end{array}$ & $\begin{array}{c}\text { Kabupaten Sukabumi, Garut, Tasikmalaya, } \\
\text { Ciamis, Cirebon, Indramayu, Subang, } \\
\text { Purwakarta, } \\
\text { Pangandaran, Kota sukabumi, Kota } \\
\text { Cimahi }\end{array}$ \\
\hline
\end{tabular}

Sumber : Penulis/Hasil Penelitian

Menurut analisis Klassen Typologi tahun 2015-2019 menjelaskan bahwa wilayah Karawang, Kota Bandung, dan Kota Cirebon merupakan wilayah yang tergolong maju dan tumbuh cepat (Rapid Growth Region), hal ini menandakan bahwa ke tiga wilayah tersebut memiliki laju pertumbuhan ekonomi yang tinggi dibandingkan dengan daerah lain dan berpotensi sebagai wilayah yang makmur serta pembangunan yang merata. Daerah yang tergolong daerah berkembang cepat (Growing Region), yaitu wilayah Kabupaten Bogor, Cianjur, Kabupaten Bandung, Kuningan, Majalengka, Sumedang, Kota Bogor, Kota Bekasi, Kota Depok dan Kota Tasikmalaya. Daerah ini memiliki kemampuan untuk mengembangkan wilayahnya dengan sangat besar, akan tetapi belum dilakukan pengolahan pengembangan wilayah secara optimal. Hal ini dikarenakan tingkat pembangunan yang masih relatif rendah, walaupun tingkat pertumbuhan ekonominya tinggi. Wilayah Kabupaten Bekasi, Bandung Barat, dan Kota Banjar merupakan wilayah yang tergolong daerah maju tapi tertekan (Retarted Region), hal ini disebabkan oleh laju pertumbuhan ekonomi di wilayah ini relatif lebih rendah dari Provinsi Jawa Barat, meskipun tingkat pendapatan PDRW perkapitnya lebih tinggi. Biasanya daerah ini memiliki kemampuan untuk maju akan tetapi laju pertumbuhan ekonominya mengalami penurunan akibat kegiatan utama daerah yang bersangkutan mengalami ganguan atau tekanan dari berbagai kondisi yang ada. Sementara saat ini ada 11 wilayah yang menempati posisi daerah relatif tertinggal (Underdeveloped Region) yaitu, Kabupaten Sukabumi, Kabupaten Garut, Kabupaten Tasikmalaya, Kabupaten Ciamis, Kabupaten Cirebon, Kabupaten Indramayu, Subang, Purwakarta, Pangandaran, Kota Sukabumi dan Kota Ciamis. Ke 11 wilayah tersebut memiliki laju pertumbuhan ekonomi dan PDRB per kapita lebih rendah dari PDRB Provinsi Jawa Barat. Hal inilah yang menandakan bahwa tingkat pendapatan dan kemakmuran masyarakat berada dalam kondisi yang masih relatif rendah. 


\section{Faktor yang Mempengaruhi Ketimpangan Wilayah di Provinsi Jawa Barat}

Menurut (Pritha Aprianoor, 2015) ada beberapa faktor yang mempengaruhi ketimpangan antar wilayah, antara lain, Perbedaan Sumberdaya Alam, Perbedaan kondisi demografis, Kurang lancarnya mobilitas barang dan jasa, Konsentrasi kegiatan ekonomi wilayah, dan Alokasi dana pembangunan antar wilayah

\section{Kesimpulan}

Berdasarkan hasil analisis yang telah dilakukan pada penelitian "analisis ketimpangan dan faktor yang mempengaruhi tingkat ketimpangan antar (kabupaten/kota) di Provinsi Jawa Barat" diperoleh kesimpulan sebagai berikut:

1. Produk Domestik Bruto Regional (PDRB) Provinsi Jawa Barat.

Produk Domestik Bruto Regional (PDRB) Provinsi Jawa Barat didukung oleh 17 sektor lapangan usaha Atas Dasar Harga Konstan, maka pertumbuhan PDRB Provinsi Jawa Barat tertinggi disumbang dari 3 sektor lapangan usaha yaitu, sektor Industri Pengolahan sebesar 43,37 \%, lalu disusul oleh sektor Perdagangan Besar dan Eceran; Reparasi Mobil dan Sepeda Motor sebesar 15,60 \% dan sektor Konstruksi sebesar 8,21\%. Selain itu terdapat 3 sektor lapang usaha yang memberikan sumbangan terkecil terhadap PDRB Provinsi Jawa Barat yaitu, sektor Pengadaan Listrik dan Gas sebesar 0,46 \%, disusul sektor Jasa Perusahaan sebesar 0,42 \%, dan sektor Pengadaan Air, Pengelolaan Sampah, Limbah dan Daur Ulang sebesar 0,08 \%.

2. Tingkat ketimpangan antar Wilayah di Provinsi Jawa Barat.

Berdasarkan hasil analisis tingkat ketimpangan tertinggi terjadi di wilayah Tasikmalaya dengan Indeks Williamson (tingkat ketimpangan) sebesar 1,43, wilayah Cianjur sebesar 1,42, wilayah Garut sebesar 1,34, wilayah Cirebon sebesar 1.30 dan disusul dengan wilayah Kuningan sebesar 1.28. Sementara itu wilayah dengan nilai Indeks Williamson (tingkat ketimpangan) terendah yaitu berada diwilayah Kota Bandung dengan nilai sebesar 0,25, kemudian wilayah Karawang sebesar 0,29, dan Bekasi sebesar 0,30.

3. Klasifikasi Kabupaten/kota di Provinsi Jawa Barat Tahun 2015-2019 Klasifikasi kemajuan pembangunan ekonomi menggunakan Klassen

Typologi dibagi menjadi 4 tipe, yaitu : daerah maju dan tumbuh cepat (Rapid Growth Region), meliputi wilayah Karawang, Kota Bandung, dan Kota Cirebon, daerah yang tergolong daerah berkembang cepat (Growing Region), yaitu wilayah Kabupaten Bogor, Cianjur, Bandung, Kuningan, Majalengka, Sumedang, Kota Bogor, Kota Bekasi, Kota Depok dan Kota Tasikmalaya, kemudian daerah yang tergolong maju tapi tertekan (Retarted Region) yaitu Kabupaten Bekasi, bandung Barat, dan Kota Banjar dan daerah tergolong relative tertinggal (Underdeveloped Region) yaitu Kabupaten Sukabumi, Kabupaten Garut, Kabupaten Tasikmalaya, Kabupaten Ciamis, Kabupaten Cirebon, Kabupaten Indramayu, Subang, Purwakarta, Pangandaran, Kota Sukabumi dan Kota Ciamis.

4. Faktor yang berpengaruh terhadap ketimpangan antar Kabupaten/kota di Provinsi Jawa Barat.

Ada beberapa faktor yang mempengaruhin tingkat ketimpangan antar Kabupaten/Kota di Provinsi Jawa Barat, yaitu : Perbedaan sumberdaya alam, perbedaan kondisi demografis, kurang lancarnya mobilitas barang dan jasa, 


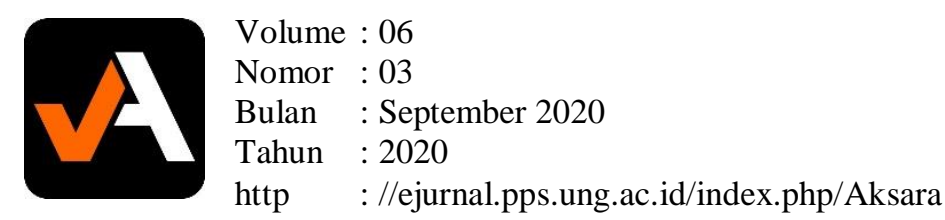

konsentrasi kegiatan ekonomi wilayah, dan alokasi dana pembangunan antar wilayah yang berbeda-beda.

\section{DAFTAR PUSTAKA}

Pritha Aprianoor, M. M. (2015). Kajian Ketimpangan Wilayah Di Provinsi Jawa Barat. Teknik Perencanaan Wilayah Kota, 4(4), 484-498.

Puspandika, B. A. (2007). Analisis Ketimpangan Pembangunan Di Era Otonomi Daerah: Hubungan Antara Pertumbuhan Ekonomi Dengan Kesejahteraan Masyarakat.

Saputra, D. (2004). Antar Kabupaten / Kota Di Provinsi Jawa Barat Analysis of Economic Growth and Disparities Between. 25, 1-18.

Sutarno, M. K. (2003). Pertumbuhan Ekonomi Dan Ketimpangan Pendapatan Antar Kecamatan. Pertumbuhan Ekonomi Dan Ketimpangan Pendapatan Antar Kecamatan, 7(1), 46-59. https://doi.org/10.15294/jejak.v7i1.3842

Tallo, A. J., Arianti, S. P., Abdillah, F., Bahri, A. S., Heryanto, S., Fassa, F., Prihandrijanti, M., \& Anshory, B. J. (2018). Typology Analysis and Leading Sector of East Nusa Tenggara Province in 2017. Journal of Physics: Conference Series, 1114(1). https://doi.org/10.1088/1742$6596 / 1114 / 1 / 012122$

Wahyu, Kiki Sarah, \& C. (2020). Urgensi Menjaga Resiliensi Di Tengah Perlambatan Ekonomi (Februari). 
Volume : 06

Nomor : 03

Bulan : September 2020

Tahun : 2020

http : //ejurnal.pps.ung.ac.id/index.php/Aksara

338 AKSARA: Jurnal IImu Pendidikan Nonformal 